Indonesian Journal of Medicine (2016), 1(3): 152-159

https://doi.org/10.26911/theijmed.2016.01.03.02

\title{
Association Between Parental Education, Occupation, Income, Language Activity, and Language Proficiency in Children
}

\author{
Hafidz Triantoro Aji Pratomo'), Rita Benya Adriani'), Muhammad Akhyar²) \\ ${ }^{1)}$ School of Health Polytechnics, Poltekkes Surakarta \\ 2)Faculty of Teaching and Educational Sciences, Sebelas Maret University, Surakarta
}

\begin{abstract}
Background: Language proficiency should be mastered by children before school admision. The process of language development was affected by cognitive and neurologic maturity. Language proficiency determine communication foundation, social, and academic interaction. Children with retardation in language proficiency may encounter problem in the social and academic relationship. This study investigated the association between parental education, occupation, income, language activity, and language proficiency in children.

Subjects and Method: This was an observational analytic study with cross sectional design. This study was conducted in Gondangrejo sub-district, Karanganyar, Central Java. A total sample of 102 children aged 4 to 5 years were selected for this study. The dependent variable was language proficiency. The independent variables were parental education, occupation, income, and language activity. The data were collected by a set of questionnaire and analyzed by multiple logistic regression.

Results: Parental education $\geq$ senior high school $(\mathrm{OR}=2.95 ; 95 \% \mathrm{CI}=1.03$ to 8.39; $\mathrm{p}=0.043)$, employed parents $(\mathrm{OR}=3.45 ; 95 \% \mathrm{CI}=1.27$ to $9.39 ; \mathrm{p}=0.015)$, family income $\geq$ regional minimum wage $(\mathrm{OR}=6.35 ; 95 \% \mathrm{CI}=2.02$ to $19.93 ; \mathrm{p}=0.002)$, and intense language activity $(\mathrm{OR}=4.32 ; 95 \%$ $\mathrm{CI}=1.61$ to $11.51 ; \mathrm{p}=0.003$ ) were associated with better language proficiency.

Conclusion: Parental education $\geq$ senior high school, employed parents, family income $\geq$ regional minimum wage, and intense language activity are associated with better language proficiency.
\end{abstract}

Keywords: parental education, occupation, language activity, language proficiency, children

\section{Correspondence:}

Hafidz Triantoro Aji Pratomo. School of Health Polytechnics, Poltekkes Surakarta.

Email: hafidzpoltekkes@gmail.com

\section{BACKGROUND}

Language is needed as a communication media to interact with friends at the same age in home environment as well as academic environment. Problems on language aspect often causes social and behavioral problem on children(Botting and Contiramsden, 2000; Thatcher et al., 2008). One of the stages of language development that needs to be concerned about it the language development stage by 4-5 years of age. Mc Leod and Harrison, (2009) states that children language proficiency of 4-5 years of age is seriously needed in their daily life as well as their activities in academic en- vironment. In this stage children face different situation between home environment and school environment.

Each stage of language development should be passed properly according to children's language development milestone. Nevertheless another fact is quite opposing that quite a few children endure language problems. Children with problematic language development will find it difficult to face situations that need communication (Harrison and McLeod, 2010).

A study conducted in the United States found that $10 \%$ of 513 children of 3 years old endured language disorder (King 
et al., 2005). Another study conducted by McLeod and Harrison (2009) tried to dig out information about number of children at age 4-5 years old who endure language disorder. Study was conducted in Australia with 4,983 children as its sample. It was conducted using parents report and teacher report. Data collection was found that there were $13 \%$ children of $4-5$ years old were having below average language score.

In regional level the number of language disorder and defect are recorded as high. One of the Regencies has high number of defect in Ex-Residency of Surakarta region is Karanganyar Regency. The number of language and speech disorder in Karanganyar Regency is 626 children. Using the data, prevalence of language disorder in Karanganyar Regency is obtained that is 0.74 in every 1,000 population. Data shows that the most cases occur in Gondangrejo Sub district with 79 children (Karanganyar Central Bureau of Statistics). With the number of population is 75,226 people, the prevalence of language and speech disorder in Gondangrejo is 1.05 in every 1,000 population.

Mother plays an important role in development process of a child. Some studies show that mother has an important role in children language development (Harrison and McLeod, 2010; Dollaghan et al., 1999). Another important reason is interaction pattern and communication pattern of mother and child decide children language development during development stage. Dollaghan et al., (1999) finds that socio-de-

Table 1. Study subject's characteristics

\begin{tabular}{llcc} 
Table 1. Study subject's characteristics & & \\
\hline & Variables & $\mathbf{N}$ & $\mathbf{\%}$ \\
\hline Gender types & Male & 51 & 50 \\
\multirow{2}{*}{ Mothers' occupational status } & Female & 51 & 50 \\
\multirow{2}{*}{ Parents' income } & Housewives & 54 & 52.9 \\
\multirow{2}{*}{ Mothers' education period } & Working & 48 & 47.1 \\
& Above Regional Minimum Wages & 69 & 67.6 \\
& Below Regional Minimum Wages & 33 & 32.4 \\
& Above 9 years & 36 & 35.3 \\
\hline
\end{tabular}

e-ISSN: 2549-0265 (online) mography variable: mother decides children language proficiency. The various languages are reality to be solved.

Epidemiology study that aims to know the relationship between factors related to children language development is seriously needed. The absence of intense study about factors of children language development will worsen the condition endured by society in Gondangrejo, Karanganyar Regency, considering that the sub district possesses the highest number of language disorder in Karanganyar Regency and also the majority of the populations are from middle to lower level of economy. The other impact if the research is not conducted is that would be difficult to decide strategic steps in the effort to deal with language disorder in Gondangrejo Sub district.

\section{SUBJECTS AND METHOD}

The study was observational analysis with cross sectional design. The research sample was 102 children of 4-5 years old in Gondangrejo Subdistrict, Karanganyar Regency. Teh data were collected by questionnaire and children language proficiency test. The data were analyzed by logistic regression.

\section{RESULTS}

Characteristics of the sample were distinguished based on gender types of the children, mothers' occupational status, family income, and mother's education. Subjects characteristics can be seen in Table 1 . 
The result of Chi Square test to know the association between maternal education and language proficiency was $\mathrm{p}$ equal to 0.002 with Odd Ratio was 3.79 . It showed that mothers whose education period was above 9 years education have 3.79 times bigger possibility to make their children having better language proficiency compared to children whose mothers' education is less than 9 years. The association between mothers' occupational status with language proficiency with Chi Square test showed $\mathrm{p}$ equal to 0.007 with Odd Ratio was 3.04. With ratio equal to 3.04 the result showed that unemployed mothers had 3.04 times bigger possibility to make their children having better language proficiency compared to children that mothers were employed. The association between parents' income and children's language proficiency which was analyzed with Chi Square test showed $\mathrm{p}$ value equal to 0.002 and $\mathrm{OR}=4.30$.

Table 2. Result of bivariate analysis

\begin{tabular}{|c|c|c|c|c|c|c|c|}
\hline \multirow{2}{*}{\multicolumn{2}{|c|}{ Independent variables }} & \multirow{3}{*}{ OR } & \multicolumn{4}{|c|}{ Language Proficiency } & \multirow{3}{*}{$\mathbf{p}$} \\
\hline & & & \multicolumn{2}{|c|}{ Less } & \multicolumn{2}{|c|}{ Good } & \\
\hline & & & $\mathbf{n}$ & $\%$ & $\mathbf{n}$ & $\%$ & \\
\hline \multirow[t]{2}{*}{ Mothers' Education } & Above 9 years & 3.79 & 13 & 36.1 & 23 & 63.9 & 0.002 \\
\hline & Below 9 years & & 45 & 68.2 & 21 & 31.8 & \\
\hline Mothers' & Housewives & 3.04 & 24 & 44.4 & 30 & 55.6 & 0.007 \\
\hline Occupation & Working & & 34 & 70.8 & 14 & 29.2 & \\
\hline \multirow[t]{2}{*}{ Parents' Income } & $\begin{array}{l}\text { Above Regional Minimum } \\
\text { Wages }\end{array}$ & $4 \cdot 30$ & 32 & 46.4 & 37 & 53.6 & 0.002 \\
\hline & $\begin{array}{l}\text { Below Regional Minimum } \\
\text { Wages }\end{array}$ & & 26 & 78.8 & 7 & 21.2 & \\
\hline \multirow[t]{2}{*}{ Language Activity } & Good & $5 \cdot 30$ & 18 & 36.7 & 31 & $63 \cdot 3$ & $<0.001$ \\
\hline & Less Good & & 40 & $75 \cdot 5$ & 13 & 24.5 & \\
\hline
\end{tabular}

The result shows that parents whose income was above Regional Minimum Wages had 4.30 time bigger possibility to make their children having better language proficiency compared to children whose parents' income was less than Regional Minimum Wages.

The last was the association between language activities and language proficiency that was analyzed by Chi Square test showed the value of $\mathrm{p}$ equal to $<0.001$ with Odd Ratio 5.30. It shows that parents with good language activities had 5.30 times bigger possibility to make their children having better language proficiency compared to children whose parents had less language activities. The result of Chi Square analysis can be observed in Table 2 .
The result of logistic regression shows that maternal education, occupation, income, and language activities had an association with children language proficiency. The result of logistic regression analysis can be observed in Table 3 .

Odd Ratio value of maternal education above 9 years was equal to 2.95 it means that mothers whose education was above 9 years had 2.95 times bigger possibility to have children with better language compared to mothers with education below 9 years. The result of Wald test showed that there was a relation between maternal education and children language proficiency and statistically significant ( $\mathrm{OR}=2.95 ; 95 \%$ $\mathrm{CI}=1.04$ to $8.39 ; \mathrm{p}=0.043$ ). 
Table 3. The result of logistic regression analysis on the association between education, occupation, income and language activities with children language proficiency

\begin{tabular}{lcccc}
\hline \multirow{2}{*}{ Independent Variables } & \multirow{2}{*}{ OR } & \multicolumn{2}{c}{ 95\% CI } & \multirow{2}{*}{ p } \\
\cline { 3 - 4 } & & Lower & Upper & \\
\hline Mothers' Education $\geq 9$ years & 2.95 & 1.04 & 8.39 & 0.043 \\
Housewives & 3.45 & 1.27 & 9.39 & 0.015 \\
Parents' income $\geq$ Regional Minimum Wages & 6.35 & 2.02 & 19.93 & 0.002 \\
Good Language Activities & 4.32 & 1.62 & 11.51 & 0.003 \\
-2 log likelihood & 102.4 & & & \\
Nagelkerke R ${ }^{2}$ & $40.8 \%$ & & & \\
\hline
\end{tabular}

Odd Ratio value of mothers whose occupational status was housewives was 3.45 , it means that mothers whose occupational status was housewives were likely to have 3.45 times bigger possibility to have children with good language proficiency compared to mothers whose occupational status was other than housewives. The result of Wald test shows there was an association between maternal occupational status with children language proficiency and it was statistically significant $(\mathrm{OR}=3.45 ; 95 \% \mathrm{CI}=$ 1.27 to $9.39 ; \mathrm{p}=0.015)$.

Odd Ratio value of variable of parental income above Regional Minimum Wages was 6.35. It means that parents with income above Regional Minimum Wages were likely to have 6.35 times bigger possibility to have children with good language proficiency compared to parents with income below Regional Minimum Wages. The result of Wald test shows there was an association between parental income with children language proficiency and it was statistically significant $(\mathrm{OR}=6.35 ; 95 \% \mathrm{CI}=$ 2.02 to $19.93 ; \mathrm{p}=0.002$ ). Odd Ratio value of variable of language activities was 4.32. It means that parents with good language activities were likely to have 4.32 times bigger possibility to have children with good language proficiency compared to parents with less language activities. The result of Wald test shows there was an association between language activities with children language proficiency and it was statistically significant $(\mathrm{OR}=4.32 ; 95 \% \mathrm{CI}=$ 1.62 to $11.51 ; \mathrm{p}=0.003$ ). Negelkerke value $\mathrm{R}^{2}$ was $40.8 \%$, it means that the fourth independent variables (education, occupation, income, and language activities) were able to elaborate children language development as much as $40.8 \%$ and the remainder that was 59.2 was elaborated by other factors outside the research model.

\section{DISCUSSION}

\section{The Association between Maternal Education with Children Language Proficiency}

Li dan Powdthavee (2014) found that there is a positive correlation between educational status with health status. People with higher educational status do not only consider health as important, but also will implement by avoiding harmful habits. Dollaghan et al., (1999) successfully found that there was an association between maternal education with language proficiency of 3 years old children. Language proficiency in this study was measured from children language proficiency that consists of Mean Length Utterance (MLU), Number of Different Words (NDW), Total Number of Words (TNW), Percentage of Consonants Correct (PCC). From the result of data analysis it was found that there was astrong association between maternal educational 
status with Mean Length Utterance (MLU), Number of Different Words (NDW), Total Number of Words (TNW) of 3 years old children. Therefore from the result we can draw a conclusion that this study found a relation between maternal education with children language proficiency.

Harrison and McLeod (2010) conveyed that there are 10 studies which find low educational level as the risk factor for the occurrence of language disorder and delay. From statistical test and the result of description on previous study it can be concluded that maternal education had an association with language proficiency of children in Gondangrejo Sub district Karanganyar Regency.

The Association between Maternal Occupation with Children Language Proficiency

A mother who works as a housewife will spend some of her time with her family. A mother's occurrence in children development process extremely determines the status of children development. One of development aspects which is influenced by mother's occurrence is language development. Language has started to develop since infant. The maturity of language development is influenced by nurture and nature components. Naturally human brain possesses ability to keep new information (novelty) that enables the improvement of language quality and quantity (Perkins and Kent, 1986). Miser and Hupp (2012) stated that a home environment which is ideal for language development is home environment that is full of external stimulation of receptive and expressive language. It shows that the higher stimulation and the more often language learning conducted by a mother then it will give positive impact on the development of children language.

In addition to stimulation process, a mother's presence also plays role to teach communication pattern. A child will copy communication pattern conducted by people in his/ her surrounding, one of them is a mother (Weigel et al., 2007). Therefore, a mother should offer herself to be communication role model. So that a mother is able to shape and provide language learning for children during development stage. Weigel et al (2007) added that a conducive and whole family situation as well as parents' communication pattern are two matters that have significance in improving children language proficiency. From the result of statistic test and discussion about previous studies it can be concluded that mothers' occupational status which was unemployed influenced children language development in Gondangrejo Sub district, Karanganyar Regency. Since the study found an association between occupational status and language development in quantitative, therefore a further study is needed to know qualitative association between maternal occupational status and children language development.

\section{The Association between Parental Income and Children Language Pro- ficiency.}

Family with better level of income will have more options and opportunity to get healthcare service as well as things they need in the effort to e healthy life. For example, a family with high level of income will attempt to fulfill various needs for a healthy life such as food, recreation, and school. A family with good level of income will have nutritious food in every meal. Good nutriation status will enable every member of the family to have the finest health status. In addition to food, another aspect that is easily attained by family with good level of income is housing.

Hackman dan Farah (2008) clarified that social economy status hold an effect toward children brain development. The 
review support that social economy status variable is closely related with the development of neurophysiology of a child. Maturity of neurophysiology holds direct correlation with children language development (Hackman and Farah, 2008). Better neurophysiology maturity of a child will enable the child to have better language proficiency compared to a child with less mature neurophysiology. Delayed maturity of neurophysiology will obstruct the process of language development on children. From the above elaboration on the correlation between social economy status with health status, brain development, and language proficiency, it can be concluded that variable of social economy status hold a correlation with health status, brain development and language proficiency

\section{The association between Language Activities with Children Language Proficiency}

Language activity is a learning activity conducted to provide a child with an activity that teaches language. Language activities are able to boost the development of children's vocabulary, phonology, morphology, syntax, and semantic process. Bennett et al (2002) Found that children with high language activities have better language development compared to children with lower activities. It shows that the higher language activities then the language development will have bigger opportunity develop. Language activities which can be conducted by singing, story telling, drawing, coloring, and playing a game, is an activity that can be carried out to improve children language proficiency. When singing, children will learn how a sentence holds different emotion, as well as the occurrence of prosody. Therefore, singing simultaneously will develop speaking skill and pragmatic skill. Story telling activity is able to develop children in understanding textual as well as contextual variables.

Description on a story that is continuously going on will enable children to learn receptive language proficiency. Stimulation given through stories can develop children language understanding with varied length of the stories. Beside semantic and pragmatic aspect, children will learn how the story content based on subject, setting, time of the incident, as well as the moral value contained in a story. The presented story which is equipped with written text will give good literary stimulation. Children who are exposed to literary exposure at early age hold small chance to endure literary disorder (Snow et al., 1998). Children with literary exposure enable them to learn literary since early age so that will not obstructed by literary disorder when they enter education phase . Children with stories exposure also hold better grammatical complexity compared to children with low exposure. With good grammatical children will be able to produce sentences with complexities that are in accordance with their age (Weigel et al., 2007). Based on the elaboration above and from statistical test, it is discovered that language activities held significant association with language proficiency of children in Gondangrejo Sub district, Karanganyar Regency.

Therewas a positive association which was statistically significant between maternal education and children language proficiency. The higher level of maternal education, the better children language proficiency will be $(\mathrm{OR}=2.95 ; 95 \% \mathrm{CI}=1.04$ to 8.39; value of $\mathrm{p}=0.043$ ). There was a positive association which was statistically significant between maternal occupational status and children language proficiency. Unemployed mothers have children with better language proficiency compared to 
employed mothers $(\mathrm{OR}=3.45 ; 95 \% \mathrm{CI}=1.27$ to 9.39 ; value of $\mathrm{p}=0.015)$. There was a positive association which was statistically significant between parental income and children language proficiency. The higher parental income, the better children language proficiency will be $(\mathrm{OR}=6.35 ; 95 \% \mathrm{CI}=$ 2.02 to 19.93; value of $\mathrm{p}=0.002$ ). There was a positive association which was statistically significant between language activities and children language proficiency. The better language activities, the better children language proficiency will be $(\mathrm{OR}=4.31$; $95 \% \mathrm{CI}=1.61$ to 11.51 ; value of $\mathrm{p}=0.003$ ). The result of data analysis on the association between maternal education, maternal occupation status, parental income, and language activities with children language proficiency was they simultaneously hold positive association in which the entire variables hold association with children language proficiency with value of $\mathrm{p}<0.05$.

REFFERENCE

$\overline{\text { Badan Pusat Statistik Karanganyar (2013). }}$ Karanganyar dalam angka 2013. http: //www.karanganyarkab.go.id/.Diakse s pada tanggal 02 Februari 2015.

Bennett KK, Weigel DJ, Martin SS (2002). Children's acquisition of early literacy skills: examining family contributions, Early Childhood Research Quarterly 17: 295-317.

Botting N, Conti-ramsden G (2000). Social and behavioural difficulties in children with language impairment. Child Language Teaching and Therapy 16 (2): 105-120.

Dollaghan CA, Campbell TF, Paradise JL, Feldman HM, Janosky JE, Pitcairn DN (1999). Maternal education and measures of early speech and language. Journal of Speech, Language, and Hearing Research 42: 1432-1443.
Hackman DA, Farah MJ (2008). Socioeconomic status and the developing brain. Trends in Cognitive Sciences 13(2): 65-73.

Harrison LJ, McLeod S (2010). Risk and Protective Factors Associated With Speech and Language Impairment in a Nationally Representative Sample of 4 to 5 -Year-Old Children. Journal of Speech, Language, and Hearing Research 53(2): 508-529.

King TM, Rosenberg LA, Fuddy L, McFarlane E, Sia C, Duggan AK (2005). Prevalence and early identification of language delays among at-risk three year olds. Journal of Developmental and Behavioral Pediatrics 26: 293.

Li J, Powdthavee N (2014). Does more education lead to better health habits? Evidence from the school reforms in Australia. Social Science and Medicine 30: 1-9.

Mc Leod S, Harrison LJ (2009). Epidemiology of Speech and Language Impairment in a Nationally Representative Sample of 4 to 5 year old children. Journal of Speech, Language, Hearing Research 52: 1213-1230.

Miser TM, Hupp JM (2012). The Influence of Socioeconomic Status, Home Environment, and Childcare on Child Language Abilities. Current Psychology 31(2): 144-159.

Perkins WH, Kent RD (1986). Functional Anatomy of Speech Language, and Hearing: A Primer. Boston: Allyn and Bacon.

Snow CE, Burns MS, Griffin P (1998). Preventing reading difficulties in young children: Committee on the Prevention of Reading Difficulties in Young Children, National Research Council dalam Weigel, 2007. Language development in the years before school: a comparison of developmental assets 
Pratomo et al./ Association Between Parental Education, Occupation, Income

in home and child care settings. Early Child Development and Care.

Thatcher KL, Fletcher K, Decker B (2008). Communication disorders in the school: Perspectives on academic and social success an introduction. Psychology in the Schools 45(7): 579581 .
Weigel DJ, Lowman JL, Martin SS (2007). Language development in the years before school: a comparison of developmental assets in home and child care settings. Early Child Development and Care 177 (6-7): 719-734. 